\title{
PENERAPAN METODE PEMBELAJARAN STORYTELLING DALAM UPAYA MENINGKATKAN MINAT MEMBACA SISWA KOBER AS-SYAFA'AH
}

\author{
Lilis Saidah Napisah \\ Lilissaidah2026@yahoo.com \\ Yane Devi Anna \\ yanedevianna@yahoo.co.id
}

Dita Rari Dwi R.T

ditarari@gmail.com

\section{SEKOLAH TINGGI ILMU EKONOMI EKUITAS}

\begin{abstract}
ABSTRAK
Kegiatan pengabdian pada masyarakat yang dilaksanakan di Kober As-Syafa'ah, bertujuan untuk membantu mengatasi permasalahan yang tengah dihadapi oleh pengelola Kober AsSyafa'ah terkait dengan usaha untuk meningkatkan minat baca peserta didik di Kober AsSyafa'ah melalui kegiatan pengenalan metode pembelajaran menggunakan metode story telling. Kegiatan ini dilaksanakan melalui program pendampingan dalam melakukan kegiatan pengenalan metode story telling dalam pembelajaran di Kober As-Syafa'ah. Pelaksanaan pengabdian dilakukan dari mulai pelaksanaan persiapan dengan menyediakan perangkat pembelajaran story telling berupa penyediaan berbagai buku cerita anak, hingga pengenalan cara pelaksanaan story telling dalam pembelajaran. Adapun luaran produk dari program tersebut modul pembelajaran strorytelling yang dilengkapi dengan alat bantu berupa alat peraga sesuai kebutuhan di Kober As-Syafaah.
\end{abstract}

Kata kunci: Metode Pembelajaran, Storytelling, Kelompok Bermain.

\section{PENDAHULUAN}

Pendidikan anak usia dini merupakan program yang dicanangkan pemerintah untuk memenuhi kebutuhan pertumbuhan dan perkembangan anak, seperti tercantum pada Undang-Undang No. 20 Tahun 2003 pasal 1 ayat 14 tentang Sistem Pendidikan Nasional yang menyebutkan bahwa : "Pendidikan anak usia dini adalah suatu upaya pembinaan yang ditujukan kepada anak sejak lahir sampai usia enam tahun yang dilakukan melalui pemberian rangsangan pendidikan untuk membantu pertumbuhan dan perkembangan jasmani dan rohani anak agar anak memiliki kesiapan dalam memasuki pendidikan lebih lanjut.

Kober As-Syafa'ah yang terletak di Desa Cihanjuang memiliki anak didik yang rata-rata orang tuanya memiliki bidang pekerjaan sebagai buruh tani dan buruh pabrik. Kesibukan para orang tua peserta didik membuat kurangnya bimbingan di rumah, Selain itu dengan keterbatasan ekonomi mereka sulit untuk membeli buku bacaan untuk putra/putrinya, sehingga minat membaca anak-anak menjadi kurang. Untuk meningkatkan minat baca bagi peserta didik, 
Kober As-Syafa'ah merupakan salah satu lembaga pendidikan usia dini dalam rangka mengembangkan kegiatan yang bisa mengembangkan kecerdasan bahasa anak melalui metode storytelling.

Keterampilan menyimak menjadi salah satu bagian keterampilan berbahasa yang harus diajarkan kepada para peserta didik dan harus dikuasai oleh para peserta didik (Aliyah, 2011). Keterampilan menyimak dapat dilatih dan diajarkan pada para peserta didik melalui metode cerita storytelling, dimana metode ini memiliki beberapa manfaat bagi peserta didik. Manfaat tersebut diantaranya yaitu dapat meningkatkan kemampuan peserta didik dalam berkomunikasi dengan baik serta dapat membentuk karakter peserta didik, melatih sportivitas peserta didik, memberikan sentuhan manusiawi, serta mengembangkan kemampuan peserta didik dalam berbahasa melalui pesan yang tersirat dan tersurat di dalam storytelling yang di perdengarkan kepada para peserta didik.

Hingga saat ini Kober As-Syafa'ah telah meluluskan 108 peserta didik dan terhitung mulai tahun 2011 sampai dengan 2019, Kober As-Syafa'ah memiliki 304 peserta didik dengan rincian sebagai berikut: Tabel 1. Data Perkembangan Jumlah Siswa

\begin{tabular}{|c|c|}
\hline Tahun Ajaraan & Jumlah Siswa \\
\hline $2011 / 2012$ & 54 anak \\
$2012 / 2013$ & 45 anak \\
$2013 / 2014$ & 31 anak \\
$2014 / 2015$ & 33 anak \\
$2015 / 2016$ & 30 anak \\
$2016 / 2017$ & 32 anak \\
$2017 / 2018$ & 33 anak \\
$2018 / 2019$ & 23 anak \\
$2019 / 2020$ & 23 anak \\
\hline
\end{tabular}

Analisis terkait kondisi dan potensi wilayah dari segi fisik dan sosial maupun lingkungan yang relevan dengan kegiatan yang akan dilakukan adalah sebagai berikut:

\section{Segi Fisik}

Dalam menjalankan kegiatan belajar mengajar, Kober As-Syafa'ah telah memiliki bangunan sendiri berkat adanya kerjasama dengan pihak pemerintah dan ditunjang dengan 1 orang kepala sekolah dan dua orang guru kelas/kelompok. Adapun fasilitas yang ada di Kober As-Syafa'ah yaitu 2 ruang kelas, 1 ruang kepala sekolah, WC, tempat cuci tangan.

2. Segi Sosial

Untuk masyarakat yang berada di sekitar wilayah Kober As-Syafa'ah, sudah mengetahui lokasi berikut akses jalan menuju lokasi. Namun bagi masyarakat yang berada di luar wilayah tersebut, khususnya yang berada di luar wilayah Sumedang secara umum belum mengetahui keberadaan Kober AsSyafa'ah tersebut. Kurangnya ketersediaan informasi yang berkaitan dengan eksistensi juga menjadi salah satu faktor yang menyebabkan As syafaah tersebut belum dikenal secara umum.

3. Segi Ekonomi

Perekonomian masyarakat di sekitar Kober As Syafa'ah banyak bekerja di bidang pertanian dan bekerja di pabrik, sehingga dalam hal perhatian pada pendidikan anak usia dini belum terlalu banyak merespon, karena banyak orang tua yang langsung menyekolahkan anaknya ke SD.

4. Segi Metode Pembelajaran

Metode pembelajaran di Kober As Syafa'ah masih menggunakan metode klasikal, yaitu pembelajaran hanya berpusat pada guru, bukan pada anak, sehingga kreatifitas anak kurang terasah. Berdasarkan uraian tersebut, kami tertarik untuk mengadakan program pengabdian pada masyarakat terkait dengan pengenalan metode storytelling di Kober As-Syafa'ah. Hal ini dimaksudkan untuk membantu pengelola Kober As-Syafa'ah dalam rangka untuk melatih dan menumbuhkan minat baca serta keampuan menyimak dan berkomunikasi bagi para peserta didik di Kober As-Syafa'ah.

\section{METODOLOGI PELAKSANAAN}


Metode pelaksanaan dalam melakukan pengabdian masyarakat antara lain:

1. Melakukan survei pendahuluan untuk mengetahui kondisi Kober As-Syafa'ah secara umum seperti fasilitas dan kondisi lingkungan maupun yang bersifat khusus yang berkaitan dengan proses pembelajaran serta metode pembelajaran yang saat ini digunakan.

2. Menyusun rencana perbaikan dari hasil survei pendahuluan yang sudah dilakukan dan mengkomunikasikan kepada pengelola Kober As-Syafa'ah mengenai program yang akan dilaksanakan disertai dengan jadwal kegiatan.

3. Pemberian pelatihan dalam pengembangan metode pembelajaran storytelling di Kober As-Syafa'ah.

4. Pendampingan dalam penerapan pengembangan metode pembelajaran storytelling.

5. Melakukan evaluasi atas penerapan metode pembelajaran storytelling dengan membandingkan hasil survei pendahuluan dengan sesudah penerapan.

Adapun media yang digunakan dalam pelatihan dengan menyediakan prasana untuk menerapkan metode story telling berupa buku panduan pelaksanaan pengembangan metode pembelajaran storytelling, serta buku cerita, alat peraga seperti boneka, mainan jenis binatang dan film animasi anak sebagai media penunjang pengembangan metode pembelajaran.

Kegiatan pendampingan direncanakan akan dilakukan selama 3 (tiga) bulan.

\section{HASIL DAN LUARAN}

Metode Pembelajaran di Kober As-Syafa'ah 1. Pengamatan Proses Pembelajaran yang Berjalan Saat Ini

Kegiatan ini dilakukan pada bulan November tahun 2019. Adapun tujuan dari kegiatan ini adalah untuk mengamati bagaimana proses pembelajaran yang dilaksanakan di Kober As-Syafa'ah dan keterlibatan siswa dalam pembelajaran.

Pada tahap ini diperoleh informasi terkait pelaksanaan proses pembelajaran yang dilakukan di Kober As-Syafa'ah, yakni masih berupa pembelajaran yang bersifat tutorial, dimana guru menjelaskan kepada murid dan memberikan latihan atas materi yang diberikan. Dengan metode tersebut siswa lebih cenderung pasif karena hanya mendengarkan dan siswa kurang memahami apa yang disampaikan karena merasa pembelajaran yang serius. Selain itu program membaca buku belum dilakukan secara rutin, sehingga minat baca dari siswa masih kurang.

2. Perancangan Metode PembelajaraN yang Efektif

2.1 Metode Pembelajaran Storytelling

$$
\text { Menurut Asfandiyar (2007:2) }
$$

storytelling merupakan sebuah seni bercerita yang dapat digunakan sebagai sarana untuk menanamkan nilai-nilai pada anak yang dilakukan tanpa perlu menggurui sang anak. Dalam kegiatan storytelling, proses bercerita menjadi sangat penting karena dari proses inilah nilai atau pesan dari cerita tersebut dapat sampai pada anak.

Storytelling dengan media buku, dapat digunakan Guru TK untuk memberikan pengalaman yang menyenangkan terhadap siswa. Di masa sekarang, bercerita memang merupakan hal yang jarang dilakukan. Peran dan fungsinya sudah banyak tergantikan oleh tayangan televisi dan bermain game di komputer. Terlepas dari semua itu, cerita memiliki kekuatan, fungsi dan manfaat sebagai media komunikasi, sekaligus sebagai metode dalam membangun kepribadian anak. Dengan adanya kegiatan storytelling diharapkan dapat memberikan pengaruh positif pada penanaman karakter anak.

\subsection{Manfaat Storytelling}

Menurut Itadz (2008:81-97), berbicara mengenai storytelling sungguh banyak manfaatnya. Kegiatan storytelling ini penting untuk dilakukan terutama dalam masa tumbuh kembang anak. Selain itu, mendongeng memiliki banyak manfaat bukan hanya bagi anak tetapi juga bagi orang yang mendongengkannya. Adapun beberapa manfaat dari storytelling diantaranya sebagai berikut: 
1. Membantu pembentukan pribadi dan moral anak.

2. Menyalurkan kebutuhan imajinasi dan fantasi anak.

3. Memacu kemampuan verbal anak.

4. Merangsang minat menulis dan membaca anak.

5. Membuka cakrawala pengetahuan anak.

3. Pelaksanaan Metode Pembelajaran Storytelling

Para guru diberi pembekalan mengenai metode storytelling dan mempersiapkan apa saja yang diperlukan terutama buku-buku mana yang menarik yang akan dijadikan pada saat menerapkan metode storytelling. Adapun beberapa persiapan yang dapat dilakukan dalam pelaksanaan storytelling antara lain (DS, 2018):

1. Siswa diberikan kebebasan untuk memilih sendiri buku cerita yang akan dibacakan guru. Pembacaan buku cerita, dilakukan di kelas atau di halaman dan anak-anak yang menyediakan bahan bacaan.

2. Persiapkan buku-buku cerita yang sesuai dengan tingkat perkembangan anak, baik tulisan, pilihan kata, isi cerita, panjang cerita, maupun ilustrasinya.

3. Bacakanlah cerita dengan lafal yang baik dan menarik.

4. Sediakan selalu buku-buku cerita dalam jangkauan anak.

Setelah tempat dan buku dipilih oleh murid, maka selanjutnya guru mempersiapkan langkah-langkah agar metode storytelling ini bisa berjalan lancar. Adapun langkah-langkah yang dapat dilakukan guru antara lain adalah (Shakuntala, 2018):

a. Tempat Storytelling

Kegiatan mendongeng dilaksanakan di ruang kelas. Posisi duduk pendongeng dengan memposisikan anak-anak pada posisi yang baik untuk mendengarkan dongeng. Pendongeng duduk di tempat yang sesuai dan mulai melakukan storytelling.

b. Bahasa Dongeng
Bahasa dalam storytelling menggunakan gaya bahasa yang lebih tinggi dari gaya bahasa anak sehari-hari tetapi lebih ringan dibandingkan gaya bahasa dongeng dalam buku, namun tetap mudah dipahami oleh anak.

c. Intonasi Pendongeng.

Dalam dongeng mencakup pengantar, rangkaian peristiwa, konflik yang muncul dalam cerita, dan klimaks

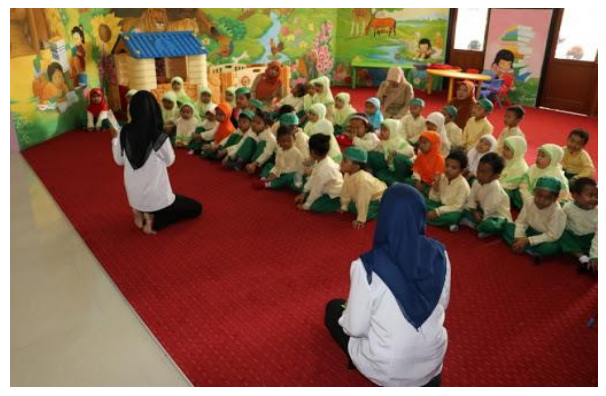

Gambar 1

Pelaksanaan Metode storytelling di Kober As Syafaah

\section{Evaluasi Penerapan Metode Pembelajaran Storytelling}

Adapun indikator minat baca pada anak usia dini atau anak taman kanak-kanak, menurut Kusmiadi (2008) dapat dilihat dari tahapan proses kegemaran membaca yang berkaitan erat dengan sebuah kerangka tindakan AIDA (Attention, Interest, Desire dan Action), yaitu:

1. Perhatian (attention) terhadap kegiatan membaca. Perhatian dapat dilihat dari perilaku siswa yang mulai tertarik terhadap buku bacaan dengan mengamati sampul buku dan membuka halaman buku bacaan.

2. Ketertarikan (interest) terhadap kegiatan membaca. Ketertarikan ditunjukan dengan siswa aktif mencari buku bacaan yang disukai dan bertanya terkait buku bacaan yang disukainya.

3. Keinginan (desire) terhadap kegiatan membaca, ditunjukan dengan mulai membaca dalam buku bacaan dan dapat menceritakan isi bacaan dengan menggunakan kata-kata sendiri untuk menilai tingkat pemahaman anak. 
4. Tindak lanjut (action) terhadap kegiatan membaca, anak akan antusias dengan mengunjungi tempat bacaan dan ingin meminjam buku pulang ke rumah.

Pengukuran untuk mengukur efektivitas penerapan metode ini dilakukan selama sebulan dilakukan rutin di sekolah dengan penambahan buku bacaan. Pengukuran dilakukan dengan membandingkan hasil survei sebelumnya dan sesudah penerapan metode storytelling. Adapun dilakukan kepada 23 orang siswa kelompok bermain. Tabel 1 menunjukan progress dari meningkatkan minat membaca para siswa, Adapun peningkatan jumlah siswa ditunjukan dalam prosentase sebagai berikut:

Tabel 2. Pengukuran Penerapan Metode Storytelling

\begin{tabular}{|c|c|c|c|c|}
\hline No & Indikator & Butir Pengamatan & Sebelum & Sesudah \\
\hline & \multirow{2}{*}{$\begin{array}{l}\text { Perhatian } \\
\text { (attention) } \\
\text { terhadap kegiatan } \\
\text { membaca }\end{array}$} & $\begin{array}{l}\text { Anak melihat-lihat sampul } \\
\text { bacaan }\end{array}$ & $30 \%$ & $55 \%$ \\
\hline & & $\begin{array}{l}\text { Anak membuka-buka } \\
\text { halaman bacaan }\end{array}$ & $35 \%$ & $60 \%$ \\
\hline \multirow[t]{2}{*}{2} & \multirow{2}{*}{$\begin{array}{l}\text { Ketertarikan } \\
\text { (interest) } \\
\text { terhadap kegiatan } \\
\text { membaca }\end{array}$} & $\begin{array}{l}\text { Anak mencari bacaan yang } \\
\text { disukainya }\end{array}$ & $25 \%$ & $40 \%$ \\
\hline & & $\begin{array}{l}\text { Anak mulai bertanya-tanya } \\
\text { tentang isi bacaan }\end{array}$ & $10 \%$ & $25 \%$ \\
\hline \multirow[t]{2}{*}{3} & \multirow{2}{*}{$\begin{array}{l}\text { Keinginan } \\
\text { (desire) terhadap } \\
\text { kegiatan } \\
\text { membaca. }\end{array}$} & $\begin{array}{l}\text { Mampu membaca kata } \\
\text { berdasarkan tulisan }\end{array}$ & $30 \%$ & $40 \%$ \\
\hline & & $\begin{array}{l}\text { Mampu memahami isi dalam } \\
\text { cerita yang dibaca }\end{array}$ & $20 \%$ & $35 \%$ \\
\hline \multirow[t]{2}{*}{4} & \multirow{2}{*}{$\begin{array}{l}\text { Tindak lanjut } \\
\text { (action) terhadap } \\
\text { kegiatan } \\
\text { membaca. }\end{array}$} & $\begin{array}{l}\text { Anak mulai tertarik untuk } \\
\text { berkunjung ke tempat baca }\end{array}$ & $25 \%$ & $50 \%$ \\
\hline & & $\begin{array}{l}\text { Anak mulai tertarik } \\
\text { meminjam buku dari sekolah }\end{array}$ & $15 \%$ & $30 \%$ \\
\hline
\end{tabular}

Dengan mengadakan pengukuran di atas, yang dilakukan sebelum dan sesudah pelaksanaan metode storytelling, maka dapat diambil kesimpulan terkait hasil yang dicapai oleh setiap anak didik di Kober AsSyafa'ah, diantaranya adalah:

1. Adanya peningkatan dalam perhatian terhadap buku, dalam tabel 1 menunjukan peningkatan sekitar $30 \%$ dari sebelum menerapkan metode storytelling.

Setelah buku cerita yang dibacakan oleh guru, murid-murid sebagian mulai tertarik untuk melihat-lihat sampul bacaan dan membuka-buka halaman bacaan dari buku cerita.

2. Ketertarikan terhadap kegiatan membaca meningkat.

Hal ini dapat terlihat dari banyaknya murid-murid yang mencari bacaan lain dan mulai bertanya-tanya tentang isi bacaan serta meminta buku lain yang sejenis.

3. Keinginan terhadap kegiatan membaca menunjukan prosentase yang paling kecil peningkatannya dibandingkan dengan indicator lainnya. Hal tersebut dikarenakan Sebagian dari siswa ada yang belum bisa membaca. Bagi murid yang sudah dapat membaca, terlihat berusaha untuk terus membaca dan sebagian yang belum dapat membaca dengan antusias meminta guru untuk mengajarkan mereka membaca. Bagi yang sudah bisa membaca, guru meminta murid menceritakan dengan bahasanya sendiri untuk diceritakan kepada teman-temannya, terutama yang belum dapat membaca, Guru dapat mengevaluasi apakah dapat memahami buku yang dibacanya atau tidak.

Tindak lanjut terhadap kegiatan membaca, dapat dilihat sebagian siswa setelah sampai sekolah sudah memulai menghampiri rak buku yang disediakan dan mulai tertarik untuk meminjam buku untuk dibawa pulang. Selain itu banyak yang ingin buku yang lain karena jumlah buku yang tersedia di sekolah, jumlahnya masih terbatas.

\section{KESIMPULAN DAN SARAN}

Pelaksanaan pengabdian masyarakat pada Kober As Syafaah dengan metode pembelajaran storytelling dapat disimpulkan sebagai berikut:

a. Minat membaca siswa setelah menerapkan metode pembelajaran storytelling menjadi meningkat.

b. Siswa lebih interaktif dan lebih mudah memahami pada saat guru membaca buku dengan menggunakan metode storytelling.

c. Sebaiknya dalam pelaksanaan metode storytelling, dapat dilakukan secara berkesinambungan dengan ditunjang oleh media pembelajaran yang dalam hal ini adalah menambah ketersediaan buku-buku cerita dapat lebih bervariasi. Hal ini dimaksudkan agar para peserta 
didik dapat memperoleh buku-buku bacaan yang berbeda dan menarik sehingga diharapkan dapat meningkatkan minat baca peserta didik. Selain itu, para pendidik juga dapat memberikan teladan bagi para peserta didik dalam melakukan pembiasaan membaca dan menyimak dengan baik cerita yang disampaikan.

\section{DAFTAR PUSTAKA}

Aliyah, S. (2011), Kajian Teori Metode Storytelling Dengan Media Panggung Boneka Untuk Meningkatkan Kemampuan Menyimak dan Berbicara Anak Usia Dini: Studi Eksperimen Quasi di TK Negeri Pembina Kabupaten Majalengka. Tesis. Universitas Pendidikan Indonesia

Asfandiyar, A. Y. (2007). Cara Pintar Mendongeng, Jakarta: Mizan.

Dewi. S. (2011). Jadikan Anak Anda Jenius, Jakarta: PT Gramedia.

Agus, DS. (2010). Pintar Mendongeng Dalam 5 Menit, Yogyakarta: Kanisius. Agus, DS. (2018). Mendongeng Bareng Kak Agus DS Yuk. Yogyakarta: Kanisius.

Itadz. (2008). Cerita Untuk Anak Usia Dini. Yogyakarta: Tiara Wacana

Kusmiadi, A. dkk. (2008). Strategi Pembelajaran PAUD Melalui Metode Dongeng Bagi Pendidik PAUD. Jurnal Ilmiah VISI PTK-PNF.

Undang-Undang No. 20 Tahun 2003 Pasal 1 ayat 14 tentang Sistem Pendidikan Nasional. 